\title{
CHURCH'S RESPONSE AS NOSTRUM TO THE CHALLENGES OF STUDENT ACTIVISM MOVEMENT IN NIGERIAN HIGHER INSTITUTION OF LEARNING
}

\author{
Mary Olubunmi Adebayo \\ Lecturer, Baptist College of Theology, Lagos, Nigeria
}

Article DOI: https://doi.org/10.36713/epra8806

DOI No: 10.36713/epra8806

\begin{abstract}
Students' populace serves as a key stakeholder in education which cannot be disregarded in decision making. Also, education impacts students with knowledge, skills and empowerment to be active in developing the society, part of the educational structure in higher education is student activism movement. Students Activism movement in higher institution of learning performs these activities to the student's populace and the society - Student Welfare, Academic development, Social Activities, Community Service, Infrastructural Development and others. Moreover, the benefits students derive in this movement are - Confidence booster, enables the student to get involved in reformation, building new connections, discovery of hidden talents and developing ability to move out of comfort zone. However, the movement is faced with diverse challenges that combat its original intention. Such challenges are - Cultism, Examination malpractice, Indiscipline, Insecurity, Frequent harassment and others. Furthermore, nostrum to the challenges of this movement is the intervention of the faith-based organization like the Church. The church is therefore, saddled with the responsibilities of constant enlightenment to the prospective students on the activity of the movement. The writer thus recommends the following to combat the challenges of student activism movement in the Nigerian higher Institution of learning - Student Activism movement should return to its original purpose of existence as enumerated by its founder, government should create enabling school climate for the students of higher institutions in Nigeria, the church should give proper enlightenment to the prospective students on the activities of student in the higher institution of learning.
\end{abstract}

KEYWORDS: Student Activism, Church, Education.

\section{INTRODUCTION}

Education is about learning for human capital and intellectual development and contribution. One of the stakeholders in education that must not be neglected is student populace. The reason is because education is the bedrock of any human endeavour in achieving development in any society. Also, education is established to enlighten, build, acquire knowledge and skills for the students and nation's growth and development. The knowledge and skills acquired through education empowers students to be active even at various citadel of learning and this empowerment birth student's activism which is part of what the write up focuses on. Besides, the church's response to the challenge of student activism is core in the paper. Students Activism is thus a group or organization in the higher institutions such as a university or college or polytechnic which o rganizes leisure activities, provides welfare services and represents students political interest.1 In the same vein, Garwe defines Student activism "as the involvement of individual students in group activities aimed at defending their interests and bringing about changes in systems, policies, attitudes, knowledge, and behaviors regarding issues affecting university life or society at large."2 Dictionary.com thus defines it as "the doctrine or practice of vigorous action or involvement as a means of achieving political or other goals, sometimes by demonstrations, protests, etc."3 The three definitions imply that students activism involves the activities performed by the students of higher education of learning to defend their interest for the purpose of change and possibly preparing them for politicism (that is, developing political zeal). Students' activism does adopt protest, demonstration and others to ventilate their grievance. In addition, student's activism birthed student unionism.

\section{HISTORY OF STUDENTS ACTIVISM IN NIGERIA}

The birth of student activism is dated back to pre -independence. In fact, European Scientific Journal reported that, it started in 1925 with the formation of West African Student Union (WASU) by Ladipo Sholanke who was schooling in London. 
Its purpose was to unite all associations of students, particularly in West Africa to promote friendliness and brotherliness. It was also formulated to campaign against colonial exploitation, racism, political repression and social inequalities in West African colonies through the instruments of books, newspaper articles, magazines and public enlightenment programmes which gradually led to the political independence of most West African states. Moreover, the birth of student's activism in West African spread and ignite among higher institutions of learning in Nigeria. Thus, University of Ibadan was the first to begin students Unionism being the first university to be established in 1948. Its pioneer president was Kunle Adepoju. The formation of student's union in the university of Ibadan gave rise to it in other higher institutions and it resulted in a unified union called National Union of Nigerian Students (NUNS) in 1956 with Ambassador Emmanuel Obe (deceased) as its first national president. ${ }^{4}$ Though the activity of student unionism was to campaign against colonialism infliction, yet, there was redirection of focus to national development at post - independence. ${ }^{5}$

It is worthy of note that student unionism which was birth from student activism was respected by government, students and various management across the country in its early days. The reason for the respect is its ideological based, high sense of intellectual; resistance to oppression tendencies, policies of government and administrators against institutions of higher learning. ${ }^{4}$ However, the activity of student activism has degenerated this day and the group has deviated from its focus; some secret societies in higher institutions of learning emanated from this pressure group.

\section{ACTIVITIES OF STUDENTS ACTIVISM}

Students play a very important role in the overall functioning of higher education activities; hence, they could not be shortchanged. They have major influence in the decisions that affect school culture, they are responsible to provide and display leadership responsibility in the society. In view of this submission, this section will present some of the activities of students in the higher institutions of learning as suggested by David.

1. Student Welfare - One core reason of existence of student activism is seeking the welfare of its members. The student's union of higher institutions of learning seeks the welfare of its members through the following method - monitoring prices of goods on the campus, improving public transportation around the school, raising scholarship funds by seeking assistance, improving services in sick bays and clinics, expressing solidary support of union members during incidences such as death and other unpleasant incidents.

2. Social Activities - The students ameliorate the social life on campus through organizing parties among themselves, creating fun club such as kegite club, going on excursions, fun trips to beaches, zoos and museums, selling discounted tickets to concerts, shows, plays and cultural events and rag days.

3. Community Service - The union encourages community services such as blood donation, promoting environmental awareness campaigns, presenting gift items to charity homes and the needy, clearing of drainages, career choice training to primary and secondary schools in the host communities. This mindset persists in them during their youth service as well.

4. Infrastructural Development - Activity of students in the higher education of learning extends to developing and installing basic facilities that are of necessity to the student populace in the school environment. Such facilities are - building of students' cafeterias, viewing centers to watch matches, listen to news, union secretariat, construction of road signs, Students Park and gardens, information centers, notice boards and others as the need arise. This action of students union is in tandem with Ademola's view on student's importance in the higher education institutions that "Students play an important role in the overall functioning of the university. They have a major influence in decisions that affects the school culture. They are responsible for providing quality leadership opportunities that transcend the college experience and are applicable in one's future career path."6

5. Sport Development - It is the responsibility of the union to organize sport competitions among faculties and departments in the school society. They do this to gain vigour, to inculcate and maintain unity among student's populace. Some of the sport activities she embarks on are - football, volleyball, handball, swimming and athletics.

6. Para Military Training - Another cogent activity usually carry out by the student union is encouraging its members to join para military body for physical fitness training and security during election period. Examples of para military body joined by the students of higher institution are - MAN O WAR and Anti Cultism Enforcement. 
7. Information Dissemination - Student Unionism creates awareness to fresh and returning students via seminars, workshops, notice boards, campus magazines, banners and broadcast news from information centers. They also present orientations on ethical conduct and general aspects of the institution.

8. Engaging in Economic Activities - The student union practice entrepreneurship to forestall total dependency on government or other agents for provision of basic facilities needed by the students and to expose its members to cultivate attitude of independence and entrepreneurship. Furthermore, the body generates its fund through dues, establish commercial outfits, collect rents from stores, engage in transportation business, print $\mathrm{T}$-shirts for sale and so on.

9. Giving Award - The body gives certificate of service to hardworking members and also confer awards of excellence to deserving lecturers, staff, student leaders and people in government; also, politicians that have distinguished themselves in works of life. ${ }^{7}$

\section{BENEFITS OF STUDENT ACTIVISM IN NIGERIAN HIGHER INSTITUTIONS}

The ambiance of tertiary institution in Nigeria is a veritable ground for learning, training and development. The three things mention can be achieved on each student through the synergetic ability of student activism. Thus, Student activism movement has been of assistance to focused students who understand the aim and perspective of the group. The benefits are briefly expatiated below -

a. Move out of comfort zone - Student activism historically helps to bring our students from their comfort zone. A comfort zone is the state of mental and emotional security, this is always challenged by student activism. It creates forum for the challenge of personal ability and pursuit. There could be some forms of reluctancy to involve in meetings, organization of highprofile events and participate in activism, but overtime the comfort zone situation and reluctant disposition will be overcome and involvement in activism becomes beneficiary;

b. Self-confidence Booster - A student's break from comfort zone and engagement in student activism always stimulate selfconfidence. Setting goals, planning, accomplishment of goals, team work, participation in special meetings and events help students to be more confidence in everyday life, circumstances, programs and events;

c. Build new Connections - Student activism creates forum for building of new connections as part of the great benefit for her members. Connections with people of different class, mindset, orientation, background, experience and others;

d. Discovery of Hidden Talents - Student activism contributes positively to societal and personal values through discoveries of hidden talents by participants. It provides avenue for discovery of unknown talents by individuals to the extent that some discover analytical strength, while others become great communicators and advocates, the writing skill of some are discovered through involvement in student activism. Such discovery in turn has unquantifiable impact on the society because it makes room for local, national and international contribution cum involvement;

e. Involvement in Reformation - The world is an evolving phenomenon that needs progress as against stagnancy and stereotype disposition, hence, the need for reformation. Student activism brings about reformation in divers ways: School management reformation, School fee reformation, Student Hostel reformation, Student welfare reformation, School security reformation, school examination reformation, school and community political reformation, relationship reformation, policy making reformation, student activism reformation, social media reformation, admission process reformation, curriculum development reformation and many others, such reformations affects and impacts both the schools, host community, students school leadership and the nation at large;

f. Avenue for Future opportunities Opportunities do not come in a vacuum they are a creation of certain factors and indices part of which includes activities in student activism. The activities of student activism open up diverse of opportunities that have great future prospects in different parts of human society like in journalism, military, educational administration, advocacy, law, social media administration, strategic planning among others. ${ }^{8}$

\section{CHALLENGES CONFRONTING STUDENT ACTIVISM IN NIGERIAN HIGHER INSTITUTIONS}

As important as student activity is to students' group, school, family and other social structure of the 
society, it has its constraint that impedes its great impact in the aforementioned strata and especially, the nation. Such factors are:

a. Indiscipline - This is an act of uncontrollable behaviour or lack of self-control. Indiscipline is described within the activity of student activism to include the exhibition of three human defects which are: lack of ethics, absence of morality and the breaking of standard societal norms. Indiscipline as an ethical challenge stems from lack of respect to defect in behaviour and such other ethical misnomers; morality is relegated to the lowest ebb of life in most student activism because of the prevalence of sex abuse, rape, thuggery and such others; but standard values of good behavior, courtesy, decorum, obedient to basic rules of laws are downgraded. ${ }^{9}$

b. Examination Malpractice - Student activism promotes examination malpractices because of overwhelming involvement and engagement of some students in activism as against concentration on their main academic responsibilities. Engagements in meetings, protest and other anti-academic activities affect the concentration of students on class attendance, reading and studying which thereby leads most student activist into examination malpractices before and during examination. This could come through cohesion with lecturers providing examination questions and possible answers or through the use of class notes and other text books during examination. Examination malpractices in essence is academic fraud or academic dishonesty. Samuel Tinubu lists examination malpractices to include seven types: plagiarism, fabrication, lying, cheating, bribery, sabotage and professor-teaching misconduct; ${ }^{10}$

c. Cultist Activities - Cultism is caused by many factors which are unfortunately associated with the activities of student activism in Nigeria schools. During political electioneering on campus, student activities make use of cultist to achieve their goals. Furthermore, cultist activities are promoted through student activism because of the need for protection from harm or harassment and intimidation; there is also the place of peer group pressure which emanates from quest for social identity and also a desire to get revenge on opposing group. It can also be deduced that student activism produces emotional instability which drives students to engage in cultism and activities associated to it;

d. Drug Addiction - Ifeanyi Ezemenari associates drug abuse and addiction with cultism and invariably to student activism. The drive for strength, ruggedness and boldness to carry out student activism has led to the dangerous trend of drug abuse and addiction in schools of higher learning. Such drugs commonly in use today among student activist are: Cannabis (Also known by other street names as Mary Jane, kush, pot, Marijuana, Eja, blaze, ganja, etc.); crack (as opposed to power, crack is free base form of cocaine that can be smoked, it is heated and smoked); tramadol; codeine; Rohypnol (roofies); Aphrodisiacs and Skunk. ${ }^{11}$, 12,13

e. Unfriendly Disposition and Victimization of the host Community - The community where the university is situated sometimes becomes unfriendly and victimize the students in the environment. The issue of unfriendly disposition comes in two ways: Students becoming unfriendly to her host community and the host community becoming unfriendly to the students, whatever way it may come, this is caused by extreme prevalence of student activism and activities that negatively affects the life of comfort in the community;

f. Frequent Harassments - The frequencies of the harassments in tertiary institutions caused by student activism are on the alarming rate. The diverse types of harassments occur in different forms between two or more lecturer, harassment between two or more students, and harassment involving a student and lecturer (s). Irrespective of who is involved in such harassment, nevertheless, there are other diverse natures of harassment that can ensue at school such as sexual harassment and intimidation.

g. Insecurity- One of the greatest effects of student activity in tertiary institution is extensive insecurity that exhibits both in and off campus. Insecurity provides comfort for assaults, attacks, criminal acts of rapes, kidnapping and harassments among others. Insecurity affects regular school operation, causes lawlessness, loss of freedom, lack of free movement and such other infringement on fundamental human rights;

h. Destruction of Infrastructural facilities Activity of students sometimes leads to destruction of school and community facilities and properties. This most times causes colossal effects on the management and functioning of regular school operations ranging from office, classrooms and other educational enhancement facilities. $^{14}$ 


\section{CHURCH'S RESPONSE AS NOSTRUM TO THE CHALLENGES OF STUDENT ACTIVISM MOVEMENT}

Hijacking of the original intention of student activism from Ladipo's perspective (Its purpose was to unite all associations of students, particularly in West Africa to promote friendliness and brotherliness. It was also formulated to campaign against colonial exploitation, racism, political repression and social inequalities in West African colonies through the instruments of books, newspaper articles, magazines and public enlightenment programmes which gradually led to the political independence of most West African states) by student hooligans demands church's response to the movement of student activism in the Nigerian higher institution of learning. In the same vein, the Church is generally viewed and accepted as a body that teaches and fosters moral values such as honesty, tolerance, openness, integrity, forthrightness, love and other values for peaceful coexistence among the people of any nation. The reasons explained above on the need for Church's response is in tandem with Kalu's assertion on the role of religion in the development of politics and social in Africa, which states that "Religion plays an indispensable role in fostering values such as honesty, integrity, openness, forthrightness and tolerance." 15 Though Kalu's focus is on religion, yet, Church is the custodian of religion; hence, the assertion does align. Besides, Church's response is needed now than never, because, the adverse effect of student activism movement on the society is massive. Such activities are - incessant killing by the cultist, yahoo business, maiming, examination malpractice and so on. In light of the above reasons, church as agent of change should response in the following manner to the challenges of student activism in the society.

a. Enlightenment Programme - The Church should organize constant enlightenment programme for the prospective students to higher institution of learning about the students' activities on campus. The prospective students should be exposed to the pros and cons of being involved deeply in the movement. In addition, they should be counseled to shun social vices and all forms of criminality. ${ }^{16}$

b. Encouraging Parental Assiduity - Parental assiduity is giving constant attention to children. Intrinsically, parents are the first teachers' children encounter in life, they are to impress right values which will guide right living into their wards. However, some parents give keen attention to their vocation, profession and career than the children. Martin Jacques submits that Parents are now spending less time with their babies and toddlers. The effects are already evident in schools. In a study published by the government's Basic Skills Agency last year, teachers claim that half of all children now start school unable to speak audibly and be understood by others, to respond to simple instructions, recognise their own names or even count to five. In order to attend to our own needs, our children are neglected, our time substituted by paying for that of others, videos and computer games deployed as a means of distraction and the problem applies across the class spectrum. So-called "money-rich, time- scarce"

professionals are one of the most culpable groups. Time is the most important gift a parent can give a child, and time is what we are less and less prepared to forgo. ${ }^{17}$

Jacques assertion presents tragedy that befalls family setting as a result of parental neglect. Though his submission focuses on younger children, yet, it is a common phenomenon in some contemporary family setting. Therefore, church should encourage the church to spend time with their children to know them better.

c. Moral and Spiritual Education - Morality and Spiritual education should not be downplayed by the church. One of the core teachings of the church is moral values and spiritual affinity with God. Moreover, "Christianity pays attention to moral formation through Bible study, catechism and through other means of disseminating scripture within the family unit and the church community." "18 Thus, the church is expected to impress such teaching on the parishioners so that they can light up the dark world especially in the higher institution of learning.

d. Exemplary Living - Ideally, the church is expected to be the light and salt to the world, agent of transformation or change but the church seems to lose this function to perversion of injustice, indiscipline, corruption and other vices. Nevertheless, the church should showcase its purpose of existence to the younger generation and the world by living in the consciousness of its core values. $^{19}$

\section{RECOMMENDATIONS}

Based on this study, the writer recommends the following 
1. Student Activism movement should be mobilized to return to its original purpose of existence as enumerated by its founder.

2. Government should create enabling school climate for the students of higher institutions in Nigeria.

3. The church should give proper enlightenment to the prospective students on the activities of student in the higher institution of learning

4. Church should serve as agent of transformation in the society especially, to the younger generation.

5. The church should encourage the parents to be loyal to the divine obligation of parenting.

\section{CONCLUSION}

This paper has addressed the definition of Students Activism in higher institutions of learning in Nigeria, its history, activities, benefits to the students and society, challenges and church's response to the movement. From the study, the writer discovered that Church, government and parents have great responsibilities to perform on the students of all cadres in order to attain the values expected of all instructions at all levels to inculcate in students as stated in the Policy of education as respect for the worth and dignity of the individual, faith in man's ability to make rational decisions, moral and spiritual principles in interpersonal and human relations, shared responsibility for the common good of society, promotion of the physical, emotional and psychological development of all children and acquisition of competencies necessary for self reliance. Also, the church must impress moral values via her teachings into its adherents which will influence their community to combat the challenge of students' activism in Nigerian higher institutions. In order words, if the religious and policy of education values are inculcated, the student activism will deviate from social vices she has indulged in as against its original purpose.

\section{ENDNOTES}

\footnotetext{
l'Student Activism," Collins Dictionary , accessed 20, 2021, https://www.collinsdictionary.com/dictionary/english/stud ents-union

${ }^{2}$ Evelyn C. Garwe, Student Voice: Embracing Student Activism as a Quality Improvement Tool in Higher Education, June 7, 2017, accessed June 20,2021, DOI.10.5772/intechopen.68669.

3 “Student Activism," Dictionary, accessed June 20, 2021, https://www.dictionary.com/browse/activism
}

${ }^{4}$ Z.E.Peter and S.T. Ebimobowei, "Leadership and Student Unionism, Challenges and Solutions in the Nigerian Tertiary Education System: The Birth of Student Unionism in Nigeria," European Scientific Journal 11, no.25 (September 2015): 385.

5 M.A. Adelabu and A.O. Akinsolu, "Political Education through the University: A Survey of Nigerian University Students : Introduction," African Journal of Political Science and International Relations 3, no.2 (February 2009): 46.

6 S.T. Ademola, Educational Management: Thought and Practice: Towards a Pro-active Management of Student Affairs in the Nigerian University System: A case study of Babcock University, ed. (Ibadan: Codat Publications, 2006), 68.

7 David O.O., "Students Unionism: A Potent Instrument for the Promotion of FUTA Brand" (lecture, Leadership Retreat, NIEPA, May 9, 2013).

${ }^{8}$ Third Eye Malta, "7 Reasons why Student Activism is Beneficial," accessed July 19, 2021, http://thirdeyemalta.com/7-reasons-why-student-activismis-beneficial/

${ }^{9}$ K.Ajayi, 'The War Against Indiscipline (WAI) and its Implications for the Nigerian School System, "New Perspectives in Nigerian Education (Ibadan: Vantage Publishers Ltd, 1990):3

10 Samuel Tinubu, "Examination malpractice causes, effects, and solutions in Nigeria," December 27, 2017, accessed July 19, 2021, https://www.legit.ng/1142694-examination-malpracticeeffects-solutions-nigeria.html.

${ }^{11}$ Ifeanyi Ezemenari, "10 Causes of Cultism In Nigeria," July 10, 2018, accessed July 19, 2021, http://www.causes/ of cultism/ in Nigeria/.

${ }^{12}$ Amaechi Udefi, "The Trouble with Nigerian Universities: Bogus Policy and Speculative Ideology," Global Journal of Social Sciences 13(June, 2014):1.

${ }^{13}$ Samuel Kayode, "Drug Abuse Among Nigerian Students The Impact Of Drugs In Our Tertiary Institutions," accessed July 19, 2021, - Freedom Foundation - $\quad$ Freedom Foundation (freedomfoundationng.org).

${ }^{14}$ Gregory R. Crane, "Contextualizing Early Modern Religion in a Digital World" (lecture, Newberry Library, Chicago, September 16, 2011).

${ }^{15}$ O.U. Kalu, "African Protestant Theology," in Kalu, W, Wariboko, $N$ \& Falola, $T$ (eds.), Religions in Africa: Conflicts, Politics and Social Ethics, (The Collected Essays of Ogbu Uke Kalu), Vol. 3, (2010) :10.

${ }^{16}$ Obaji M Agbiji \& Ignatius Swart, "Religion and Social Transformation in Africa: A Critical and Appreciative Perspective," Scriptura 114 (2015):10

${ }^{17}$ Martin Jacques, "Changes in Society : Erosion on the Family", posted on September 18,2004 @ http://www.guardian.co.uk/comment/story/0,...1307401,0 0.html. Accessed on $15^{\text {th }}$ March, 2018.

18 Obaji M Agbiji \& Ignatius Swart, "Religion and Social Transformation in Africa: A Critical and Appreciative Perspective," Scriptura 114 (2015):10

${ }^{19}$ Ibid, 14. 